\title{
Review Article \\ Hybrid Organic-Inorganic Perovskites Open a New Era for Low-Cost, High Efficiency Solar Cells
}

\author{
Guiming Peng, ${ }^{1,2,3}$ Xueqing $X u^{2}$ and Gang $X u^{2}$ \\ ${ }^{1}$ Department of Chemical and Petroleum Engineering, University of Pittsburgh, Pittsburgh, PA 15261, USA \\ ${ }^{2}$ CAS Key Laboratory of Renewable Energy, Guangzhou Institute of Energy Conversion, Chinese Academy of Sciences, \\ Guangzhou 510640, China \\ ${ }^{3}$ University of Chinese Academy of Sciences, Beijing 100049, China
}

Correspondence should be addressed to Xueqing Xu; xuxq@ms.giec.ac.cn and Gang Xu; xugang@ms.giec.ac.cn

Received 12 October 2014; Revised 14 December 2014; Accepted 14 December 2014

Academic Editor: Cao Yuebin

Copyright (C) 2015 Guiming Peng et al. This is an open access article distributed under the Creative Commons Attribution License, which permits unrestricted use, distribution, and reproduction in any medium, provided the original work is properly cited.

The ramping solar energy to electricity conversion efficiencies of hybrid organic-inorganic perovskite solar cells during the last five years have opened new doors to low-cost solar energy. The record power conversion efficiency has climbed to $19.3 \%$ in August 2014 and then jumped to $20.1 \%$ in November. In this review, the main achievements for perovskite solar cells categorized from a viewpoint of device structure are overviewed. The challenges and prospects for future development of this field are also briefly presented.

\section{Introduction}

The energy crisis and environment pollution are two main worldwide challenges that would restrain the society development. Solar energy, as a clean and vast energy source, is widely believed to be a promising way to address these global issues. Converting solar energy into electricity is thought to be an effective way to harness this abundant energy source. To date, single-crystalline silicon solar cells have shown optimistic power conversion efficiency (PCE) above $24 \%$. However, the cost of manufacturing process is still very high. Searching for low-cost materials with high PCE always attracts extensive efforts from the scientists.

Fortunately, the past five years have seen hybrid organicinorganic perovskite solar cells (PSCs) performing promisingly on a low-cost avenue to the clean and vast solar energy. The ease of fabrication, abundant material source, and high PCE rapidly caught the attention of scientists.

PSCs first emerged as a liquid electrolyte based solar cell in 2009 with the PCE of only 3.8\% [1]. However, perovskite was found to be unstable in liquid electrolyte $[1,2]$. In 2012, solid-state dye-sensitized solar cell with a PCE of $10.2 \%$ [3], which was obtained by using tin containing perovskite $\mathrm{CsSnI}_{3}$ as a cosensitizer and hole conductor, N719 as a sensitizer, and the $\mathrm{CH}_{3} \mathrm{NH}_{3} \mathrm{PbI}_{3}$ perovskite sensitized solar cell on $\mathrm{Al}_{2} \mathrm{O}_{3}$ scaffold with a PCE of $10.9 \%$ are the considerable millstone and herald the coming era of perovskite solar cells [4]. Since then, PSCs have been developed at an unprecedented rate. The PCEs of PSCs have evolved rapidly during the past five years. As shown in Figure 1(a), the PCE of perovskite had been boosted up to $15 \%$ in $2013[5,6]$. Then a confirmed efficiency of $17.9 \%$ was achieved in early 2014 [7]. Subsequently, the PCE climbed to $19.3 \%$ by engineering the interface on a planar device $[8,9]$. By November 2014, a new record certified nonstabilized efficiency of $20.1 \%$ was achieved by KRICT [10].

A schematic illustration of the crystal structure of perovskite is shown in Figure 1(b). The general formula for hybrid perovskites is $\mathrm{ABX}_{3}$, where $\mathrm{A}$ is methyl ammonium, $\mathrm{B}$ is $\mathrm{Pb}(\mathrm{II})$ or $\mathrm{Sn}(\mathrm{II})$, and $\mathrm{X}$ is $\mathrm{Cl}, \mathrm{Br}$, or I, or a coexistence of several halogens. As an exciting material for solar cells, hybrid perovskites combine many in-built advantageous properties. As shown in Figure 2(d) [11], optical properties of perovskites can be tuned by varying the ratio between different halogen elements [11-13]. The most widely studied $\mathrm{CH}_{3} \mathrm{NH}_{3} \mathrm{PbI}_{3}$ is a direct bandgap semiconductor with a bandgap of $1.55 \mathrm{eV}$, which determines its absorption offset up to $800 \mathrm{~nm}$ [14]. The weak photogenerated exciton binding energy of merely $0.03 \mathrm{eV}$ facilitates the charge separation at 


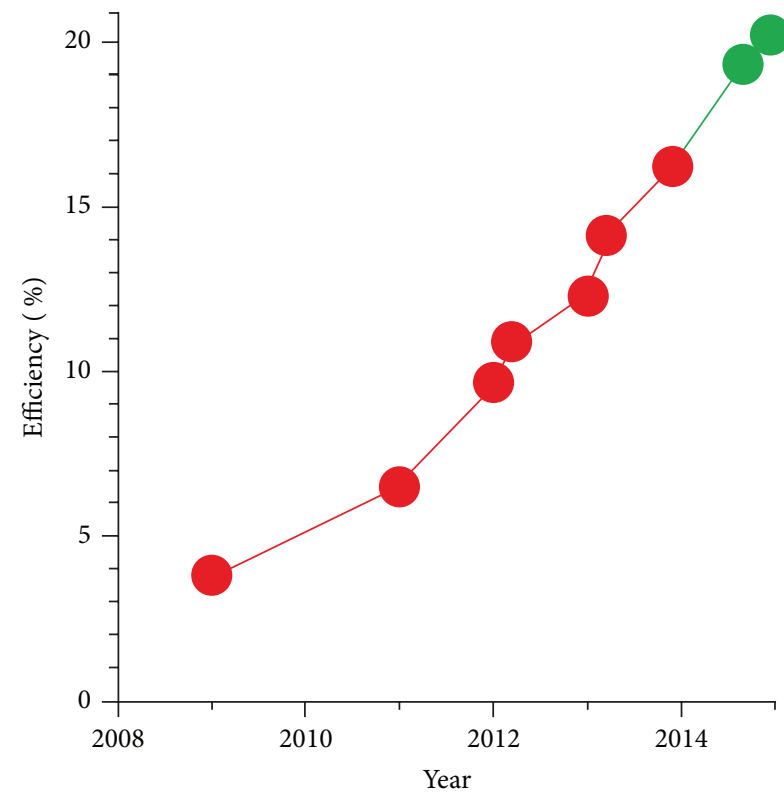

(a)

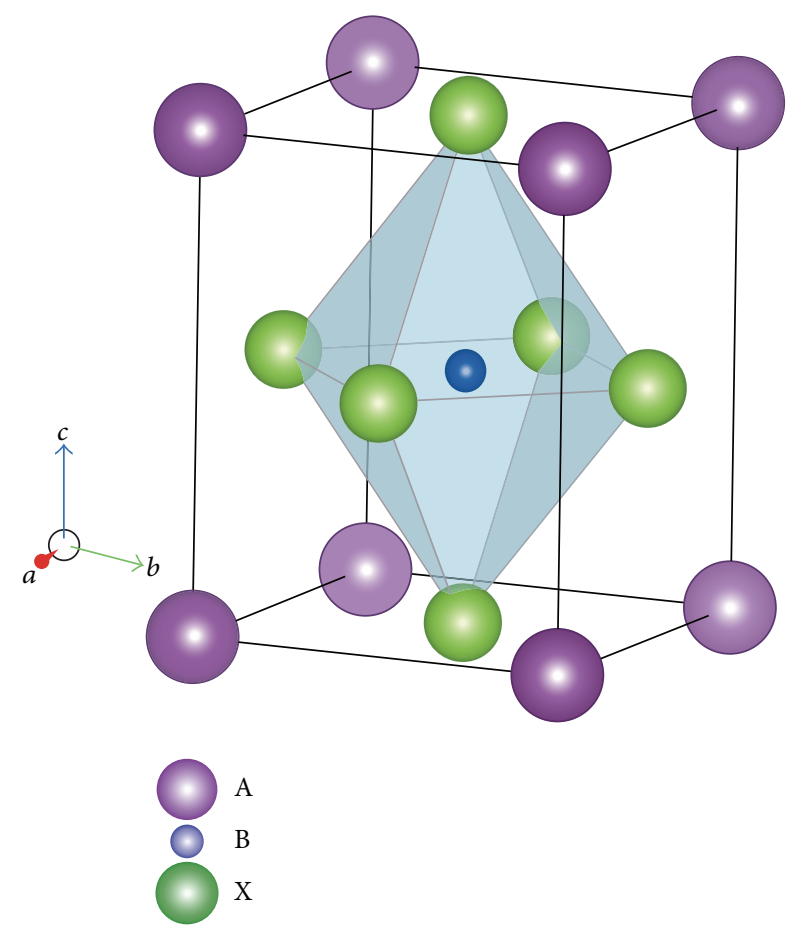

(b)

FIgURE 1: (a) PCE record plot of perovskite solar cells. Red plot is cited from the National Renewable Energy Laboratory (NREL) of the USA. Green PCE value is added according to $[9,10]$. (b) Crystal structure of perovskite adopting the form of $\mathrm{ABX}_{3}$, where A is methyl ammonium, $\mathrm{B}$ is $\mathrm{Pb}(\mathrm{II})$ or $\mathrm{Sn}(\mathrm{II})$, and $\mathrm{X}$ is $\mathrm{Cl}, \mathrm{Br}$, or I, or a coexistence of several halogen elements. Reprinted with permission from [5]. Copyright: Nature Publishing Group.

ambient temperature [15]. In addition, the small effective masses of electrons and holes generated in $\mathrm{CH}_{3} \mathrm{NH}_{3} \mathrm{PbI}_{3}$ promote rapid transport of these carriers [16]. The lifetime of the carriers is in the hundreds of nanoseconds' range, leading to much slower recombination and much longer diffusion length from $100 \mathrm{~nm}$ to $1000 \mathrm{~nm}[15,17,18]$. Apart from acting by light absorbing, hole-transporting material- (HTM-) free perovskite solar cell showing a PCE of 5.5\% highlights the efficient hole-transporting ability of $\mathrm{CH}_{3} \mathrm{NH}_{3} \mathrm{PbI}_{3}$ [19]. Furthermore, long range ambipolar charge transport was found in $\mathrm{CH}_{3} \mathrm{NH}_{3} \mathrm{PbI}_{3}$ [20]. All these material properties make perovskites attractive for photovoltaic applications.

To date, each individual layer of organic-inorganic perovskite solar cells has been investigated and optimized intensively. As the rapid development of PSCs goes on, there is a strong demand for a summary of what achievements the scientists have realized. A summary is also necessary for looking forward to address the existing issues. In this review, we would like to overview the PSCs from the following aspects: perovskite synthesis methods, hole transport materials (HTMs), and photoanode morphologies. Some outlook and challenges for PSCs also will be briefly discussed.

\section{Perovskite Synthesis and Optimization}

Two synthesis methods of hybrid perovskite are widely used in solar cell applications. The precursor $\mathrm{CH}_{3} \mathrm{NH}_{3} \mathrm{I}$ is synthesized by reacting equimolar methylamine with hydroiodic acid under stirring at $0^{\circ} \mathrm{C}$ for $2 \mathrm{~h}$. Rotary evaporation is often used to recover the $\mathrm{CH}_{3} \mathrm{NH}_{3} \mathrm{I}$ from the reaction mixture. The recovered $\mathrm{CH}_{3} \mathrm{NH}_{3} \mathrm{I}$ is washed with diethyl ether.

For the one-step method, $\mathrm{CH}_{3} \mathrm{NH}_{3} \mathrm{PbI}_{3}$ is synthesized by mixing equimolar $\mathrm{CH}_{3} \mathrm{NH}_{3} \mathrm{I}$ and $\mathrm{PbI}_{2}$ in $\gamma$-butyrolactone, $\mathrm{N}, \mathrm{N}$-dimethylformamide (DMF), or dimethylsulfoxide (DMSO) at $60^{\circ} \mathrm{C}$ for 12 hours [2]. To synthesize the mixed halides containing perovskite, the ratios between $\mathrm{CH}_{3} \mathrm{NH}_{3} \mathrm{I}$ and $\mathrm{PbX}_{2}$ are varied according to the target perovskite formula $[4,12]$. So far, the most successful one-step method case is $\mathrm{CH}_{3} \mathrm{NH}_{3} \mathrm{PbI}_{3-x} \mathrm{Cl}_{x}$ which is well illustrated by Yang group with the cell PCE of $19.3 \%$ and is summarized in Figure 2(c) [9].

The two-step method, named sequential deposition as well, is a method similar to successive ionic layer adsorption and reaction method (SILAR) for quantum dot synthesis and was developed by Burschka et al. [6]. Typically in this method, $\mathrm{PbI}_{2}$ is first dissolved in a solvent, such as $\mathrm{N}, \mathrm{N}$-dimethylformamide, under stirring at $70^{\circ} \mathrm{C}$. Then the photoanodes or substrates are spin-coated with the $\mathrm{PbI}_{2}$ solution maintained at $70^{\circ} \mathrm{C}$, followed by drying at $70^{\circ} \mathrm{C}$ for $30 \mathrm{~min}$. After cooling to room temperature, the films are dipped into a $\mathrm{CH}_{3} \mathrm{NH}_{3} \mathrm{I}$ solution (usually $10 \mathrm{mg} / \mathrm{mL}$ in 2propanol) for $20 \mathrm{~s}$ and then rinsed with 2-propanol and dried at $70^{\circ} \mathrm{C}$ for $30 \mathrm{~min}[6]$.

Other novel synthesis methods have been attempted as well. For example, vacuum condition is employed to increase the perovskite purity and uniformity $[13,24]$. Vacuum deposition, which involves evaporating and depositing organic 

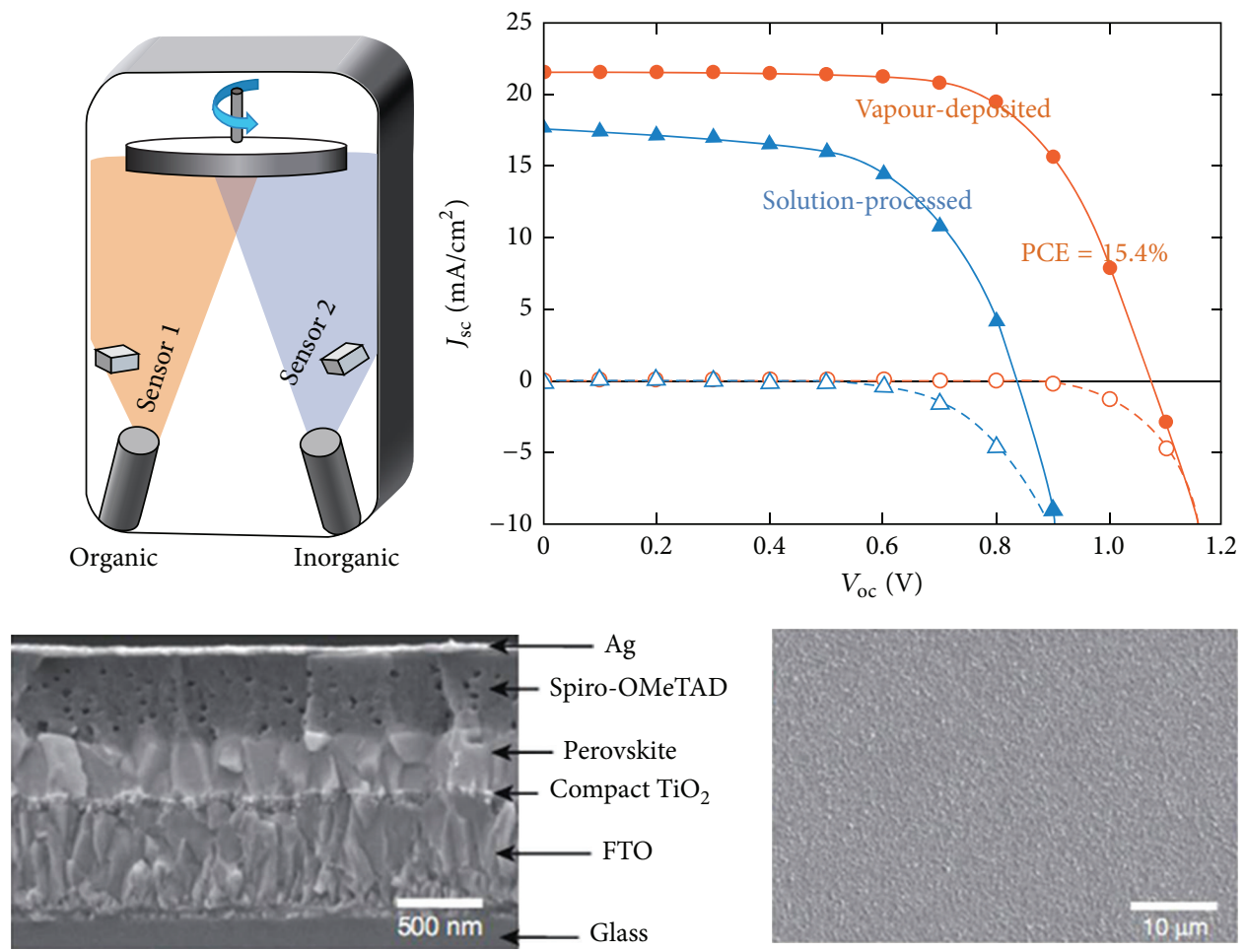

(a)
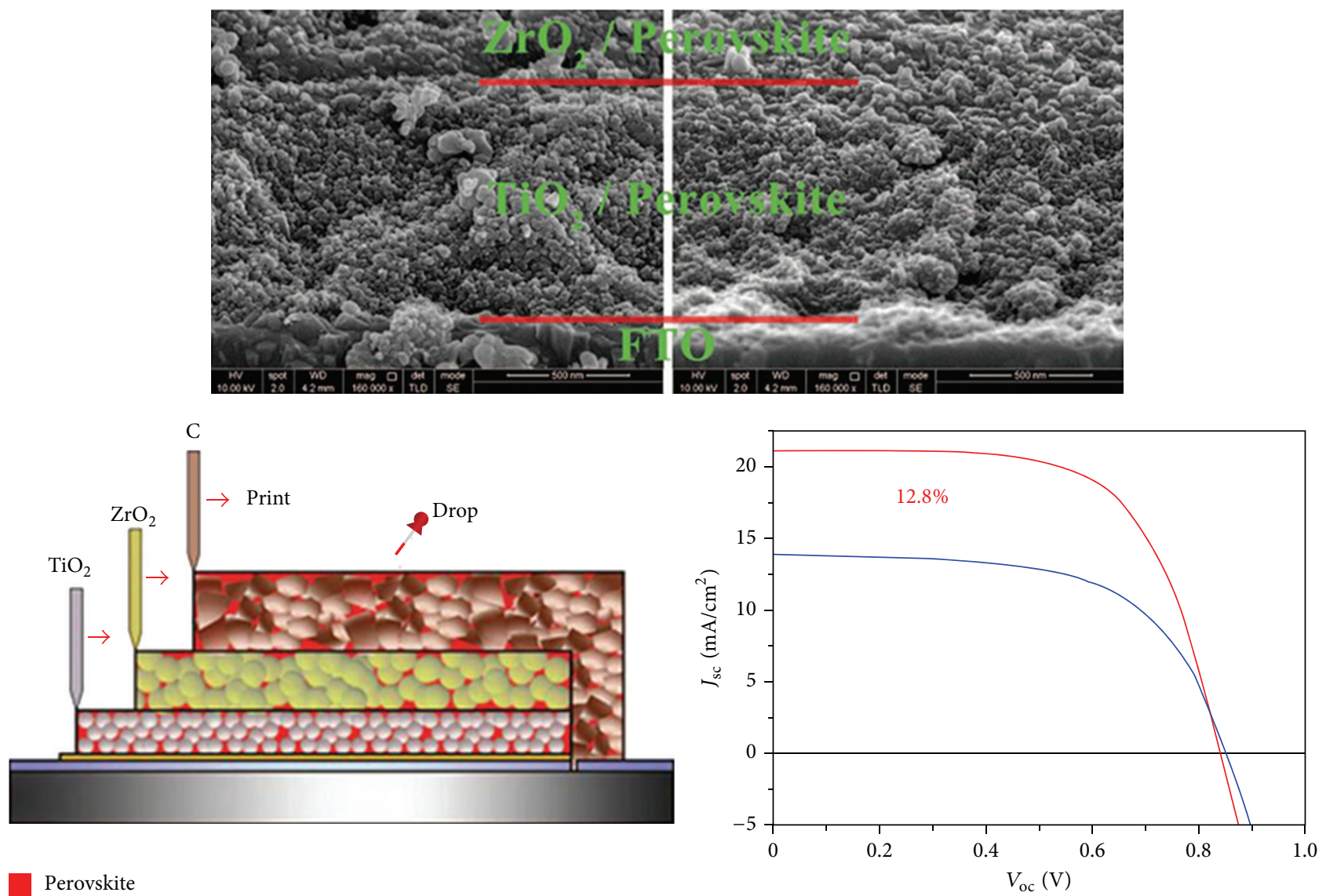

Perovskite

$\mathrm{TiO}_{2}$ layer

- $\mathrm{MAPbI}_{3}$

- $(5-\mathrm{AVA})_{X}(\mathrm{MA})_{1-X} \mathrm{PbI}_{3}$

(b)

FIgUre 2: Continued. 

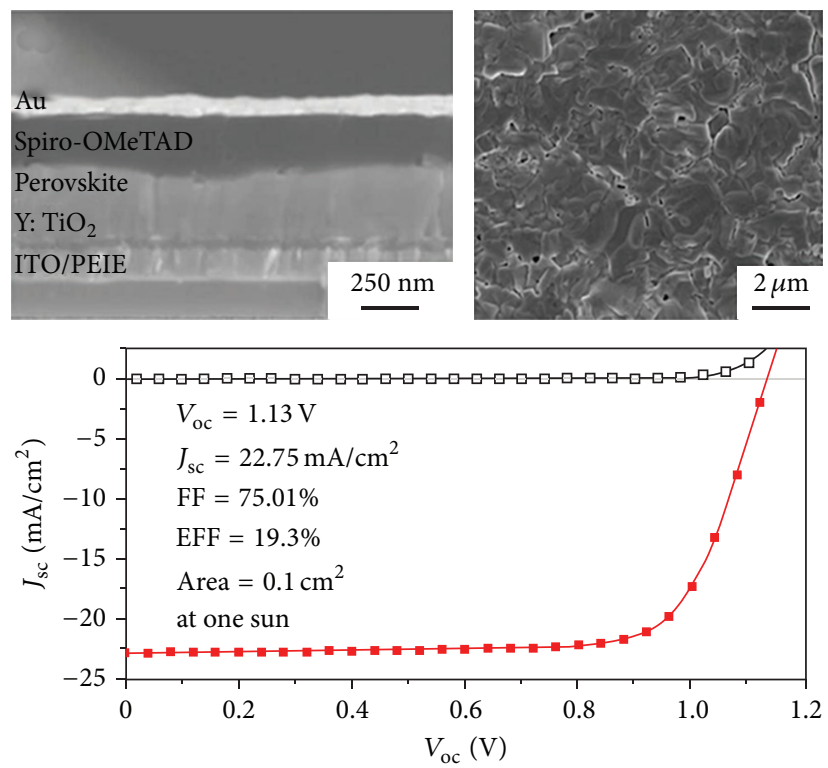

(c)
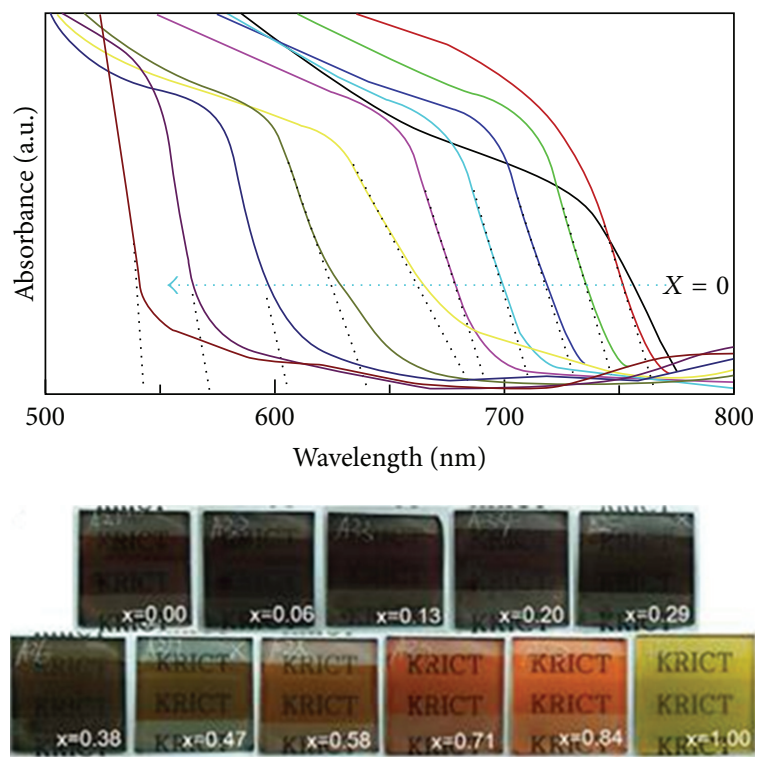

(d)

FIgure 2: Perovskite synthesis methods and light absorption tuning. (a) Vapour deposition of $\mathrm{CH}_{3} \mathrm{NH}_{3} \mathrm{PbI}_{3-x} \mathrm{Cl}_{x}$. Reprinted from [5]. Copyright: Nature Publishing Group. (b) Mixed cation perovskite ( $\left.(5-\mathrm{AVA})_{x}(\mathrm{MA})_{1-x} \mathrm{PbI}_{3}\right)$ prepared by drop-casting a solution of $\mathrm{PbI}_{2}$, methylammonium (MA) iodide, and 5-ammoniumvaleric acid (5-AVA) iodide onto a double layer of $\mathrm{TiO}_{2}$ and $\mathrm{ZrO}_{2}$ through a carbon film. Reproduced with permission from [21]. Copyright: Science. (c) Solution processed $\mathrm{CH}_{3} \mathrm{NH}_{3} \mathrm{PbI}_{3-x} \mathrm{Cl}_{x}$ with interface engineering. Reproduced with permission from [9]. Copyright: Science. (d) Colorful $\mathrm{CH}_{3} \mathrm{NH}_{3} \mathrm{~Pb}\left(\mathrm{I}_{1-x} \mathrm{Br}_{x}\right)_{3}$ obtained by tuning the chemical composition. Reprinted from [11]. Copyright: the American Chemical Society.

and inorganic sources to form perovskite, was introduced by Snaith et al. (Figure 2(a)). Such vapour-deposited planar device showed a PCE of $15.4 \%$, which was higher than that of the solution deposited device, 8.6\% [5]. In addition, planar device fabricated via a vapor-assisted solution processing generated a PCE of $12.1 \%$ by Yang group [25]. More recently, hybrid chemical vapour deposition was employed to synthesize perovskite. Such device yielded 19\% PCE according to the report [26].

Due to the nature of perovskites, finding the optimal conditions and methods necessary to obtain a dense, uniform, and high quality perovskite film still remains a challenge. There are considerable efforts by different groups to optimize the deposition conditions for high quality perovskite films. For example, Carnie et al. codeposited an $\mathrm{Al}_{2} \mathrm{O}_{3}$ /perovskite layer at $T<110^{\circ} \mathrm{C}$ by adding $5 \% \mathrm{Al}_{2} \mathrm{O}_{3}$ suspension to the $\mathrm{CH}_{3} \mathrm{NH}_{3} \mathrm{PbI}_{3}$ precursor and a solar cell was fabricated with a PCE of $7.2 \%$ [27]. In order to improve the film quality and enhance light harvesting, three ways are attempted: firstly, doping other halide atoms into $\mathrm{CH}_{3} \mathrm{NH}_{3} \mathrm{PbI}_{3}$ to improve its surface coverage and light absorption. By doping chlorine element into $\mathrm{CH}_{3} \mathrm{NH}_{3} \mathrm{PbI}_{3}$ while fabricating a planar device, perovskite annealed at $95^{\circ} \mathrm{C}$ exhibited a PCE over 10\% [28]. Colorful light absorbers based on $\mathrm{CH}_{3} \mathrm{NH}_{3} \mathrm{~Pb}\left(\mathrm{I}_{1-x} \mathrm{Br}_{x}\right)_{3}$ were synthesized by changing the I to $\mathrm{Br}$ ratio (Figure $2(\mathrm{~d})$ ). The cells using $\mathrm{CH}_{3} \mathrm{NH}_{3} \mathrm{~Pb}\left(\mathrm{I}_{1-x} \mathrm{Br}_{x}\right)_{3}$ with $x$ value from 0 to 0.2 exhibited an average PCE of more than $10 \%$ and a maximum PCE of $12.3 \%$ [11]. Extremely uniform and dense
$\mathrm{CH}_{3} \mathrm{NH}_{3} \mathrm{~Pb}\left(\mathrm{I}_{1-x} \mathrm{Br}_{x}\right)_{3}(x=0.1-0.15)$ film was obtained by using a mixed solvent of $\gamma$-butyrolactone and dimethylsulphoxide (DMSO) followed by a toluene drop-casting process when spin-coating the precursor solution [7]. Secondly, methylammonium group could be substituted by other moieties to change its bandgap and film evolution behavior $[21,29] . \mathrm{NH}_{2} \mathrm{CH}=\mathrm{NH}_{2} \mathrm{PbI}_{3}$ with its bandgap of $1.4 \mathrm{eV}$ showed $7.5 \%$ in PSC [29]. More recently, mixed organic cation perovskite was produced by drop-casting a solution of $\mathrm{PbI}_{2}$, methylammonium (MA) iodide, and 5-ammoniumvaleric acid (5-AVA) iodide onto a double layer of $\mathrm{TiO}_{2}$ and $\mathrm{ZrO}_{2}$ through a carbon film. This structured PSC led to a more stable device (>1000 h) with a PCE of $12.8 \%$ (Figure 2(b)) [21]. The deep relationship between bandgap and substituents of MA was also investigated. The bandgap of $\mathrm{CsPbI}_{3}$ is $1.67 \mathrm{eV}$ [30]. The bandgap seems to gradually increase as the size of the substituents of methylammonium group increases [31]. Thirdly, light absorption onset of perovskites could also be tuned by substituting part of the toxic lead with other nontoxic metal elements. $\mathrm{CH}_{3} \mathrm{NH}_{3} \mathrm{Sn}_{1-x} \mathrm{~Pb}_{x} \mathrm{I}_{3}$ with series of different metal ratios were synthesized. Their bandgaps were located between 1.17 and $1.55 \mathrm{eV}$. Consequently, the light absorption could be extended from the visible region to the near-infrared region $(\sim 1060 \mathrm{~nm})$, and finally the PSC using $\mathrm{CH}_{3} \mathrm{NH}_{3} \mathrm{Sn}_{0.5} \mathrm{~Pb}_{0.5} \mathrm{I}_{3}$ had a $4.18 \%$ PCE [32]. Moreover, leadfree solid-state perovskite solar cells based on $\mathrm{CH}_{3} \mathrm{NH}_{3} \mathrm{SnI}_{3}$ as the light harvester were first reported by Hao et al. with a PCE of 5.73\% [33]. 


\section{HTMs for PSCs}

HTMs, just as the name implies, transport the holes to the back electrode when the excitons are dissociated into electrons and holes. Apart from the fast hole transport rate, direct contact to the sensitizer allows HTMs to coexist with the sensitizer and not cause any sensitizer degradation.

3.1. Organic HTMs. The first PSCs adopted $\mathrm{CH}_{3} \mathrm{NH}_{3} \mathrm{PbI}_{3}$ and $\mathrm{CH}_{3} \mathrm{NH}_{3} \mathrm{PbBr}_{3}$ as the light absorber and LiI and $\mathrm{I}_{2}$ containing methoxyacetonitrile as electrolyte. Such PSCs yielded PCEs of $3.8 \%$ and $3.1 \%$, respectively [1]. However, perovskite was found to rapidly dissolve into the organic solvent. Much progress was achieved by changing the electrolyte composition and improving the perovskite deposition method. The resultant PSC achieved a PCE of $6.5 \%$, but the devices still lasted for only several minutes [2]. To resolve this dissolution issue, scientists tried to replace liquid electrolyte with solid HTMs. Perovskite CsSnI ${ }_{2.95} \mathrm{~F}_{0.05}$ was the first perovskite employed to act as both solid HTM and light absorber. Impressively, such PSC construct significantly lifted its PCE to $10.2 \%$ [3]. 2,2',7,7'-Tetrakis(N,N-dimethoxyphenyl-amine)-9, $9^{\prime}$-spirobifluorene (spiroOMeTAD) was incorporated with mesoporous $\mathrm{TiO}_{2}$ and $\mathrm{Al}_{2} \mathrm{O}_{3}$, which showed PCE of $10.9 \%$ and generated opencircuit photovoltage up to $1.1 \mathrm{~V}[4,34]$. By electron coupling with fullerene monolayer on the surface of $\mathrm{TiO}_{2}$, the device using poly(3-hexylthiophene-2,5-diyl) (P3HT) as HTM realized a PCE of $6.7 \%$, while the device using spiroOMeTAD as HTM output a PCE of $11.7 \%$ [35]. In addition, behaviors of three HTMs, spiro-OMeTAD, P3HT, and 4-(diethylamino)-benzaldehyde diphenylhydrazone (DEH), were compared in $\mathrm{CH}_{3} \mathrm{NH}_{3} \mathrm{PbI}_{3}$ sensitized solar cells [36]. Hole transfer from $\mathrm{CH}_{3} \mathrm{NH}_{3} \mathrm{PbI}_{3}$ to HTMs was observed after excitation of $\mathrm{CH}_{3} \mathrm{NH}_{3} \mathrm{PbI}_{3}$. The electron lifetime in these devices was in the order spiro-OMeTAD $>$ P3HT $>$ DEH, while the charge transport time was similar. Besides, PSC incorporated with spiro-OMeTAD showed the best performances [36]. Tris[2-(1H-pyrazol-1-yl)-4-tert-butylpyridine) cobalt(III) tris(bis (trifluoromethylsulfonyl) imide)] as an additive in spiro-OMeTAD is believed to improve PSC PCE from $8.1 \%$ to $10.4 \%$ [37]. Moreover, several other organic HTMs were also employed with perovskite to fabricate PSCs. Poly(triarylamine) is another efficient organic HTM. PSCs of $\mathrm{CH}_{3} \mathrm{NH}_{3} \mathrm{PbI}_{3}$ and $\mathrm{CH}_{3} \mathrm{NH}_{3} \mathrm{~Pb}\left(\mathrm{I}_{1-x} \mathrm{Br}_{x}\right)_{3}$ incorporated with poly(triarylamine) realized PCE over 12\% [11, 20]. When using conjugated quinolizino acridine as HTM, $\mathrm{CH}_{3} \mathrm{NH}_{3} \mathrm{PbI}_{3}$ sensitized $\mathrm{TiO}_{2}$ mesoporous PSC output a better PCE of $12.8 \%$ than using spiro-OMeTAD as HTM [38]. With $o$-methoxy substituents in spiro-OMeTAD as HTM, planar PSC achieved PCE of 16.7\% [39]. Carbazole derivatives were adopted as $\mathrm{HTMs}$ and fabricated with $\mathrm{CH}_{3} \mathrm{NH}_{3} \mathrm{PbI}_{3}$ into PSC yielding a remarkable PCE of $14.79 \%$ [40].

3.2. Inorganic HTMs. However, the cost of organic HTMs is still high. Low-priced HTMs for reducing the cost of PSCs appear appealing. Compared to organic HTMs, inorganic HTMs are less expensive and attract less attention. PSCs using copper iodide realized a PCE over $6.0 \%$ but with an inferior $V_{\text {oc }}$ of $0.55 \mathrm{~V}$ [41]. The small $V_{\text {oc }}$ for the copper iodide based PSCs originated from the unfavorable bandgap. Copper thiocyanate is a more efficient HTM for PSCs. Qin et al. adopted copper thiocyanate to incorporate with $\mathrm{CH}_{3} \mathrm{NH}_{3} \mathrm{PbI}_{3}$, and the device showed PCE of $12.4 \%$ [42]. Nickel oxide is another inorganic HTM due to its large bandgap and deep valance band $(5.4 \mathrm{eV})$. $\mathrm{NiO}$ was employed as HTM and the corresponding PSC yielded a PCE of 7.3\% [43]. PCE of $11.6 \%$ was obtained on a $\mathrm{NiO} / \mathrm{CH}_{3} \mathrm{NH}_{3} \mathrm{PbI}_{3}$ device via introducing $\mathrm{NiO}_{x}$ as electron blocking layer [44]. By employing $\mathrm{NO}$ as hole-collecting and hole-conducting layer, $\mathrm{CH}_{3} \mathrm{NH}_{3} \mathrm{PbI}_{3}$ on planar $\mathrm{NiO}$ film output a $\mathrm{PCE}$ of $7.6 \%$ with the $V_{\text {oc }}$ of $1.05 \mathrm{~V}$ [45]. By doping $\mathrm{NiO}_{x}$ thin film with copper, the hole transport ability of the resultant film increased remarkably. For the copper-doped $\mathrm{NiO}_{x}$ based PSCs, the environmental stability was much improved, and the PCE was impressively elevated to $15.40 \%$ [46].

3.3. HTM-Free PSCs. The device using $\mathrm{Al}_{2} \mathrm{O}_{3}$ as scaffold stimulated the deep thought of the property of $\mathrm{CH}_{3} \mathrm{NH}_{3} \mathrm{PbI}_{3}$ [4]. Due to the larger band gap of $\mathrm{Al}_{2} \mathrm{O}_{3}$, it could not conduct electron from perovskite to the $\mathrm{TiO}_{2}$ underlayer. The high device performance implies the high electron transport ability of the material $[47,48]$. On the other hand, the HTM-free device that generated PCE of 5.5\% confirmed the hole transport ability of the perovskite [19]. Theoretically, the high hole transport ability of $\mathrm{CH}_{3} \mathrm{NH}_{3} \mathrm{PbI}_{3}$ voids the need for using an HTM, which prompts the development of new nanocomposite solar cells: mesoporous scaffold based solar cells (Figure 3(b)). In these structured solar cells, $\mathrm{CH}_{3} \mathrm{NH}_{3} \mathrm{PbI}_{3}$ is fully infiltrated between the $\mathrm{TiO}_{2}$, and no additional space is mandatorily needed for HTMs. Such structure could save the thickness of the film to $200-300 \mathrm{~nm}$. Poly(triarylamine) was used as HTM for this new PSC and attained PCE of $12 \%$, suggesting the carrier collection by hole transport through the perovskite was quite effective [20]. By using hybrid composite of single-wall carbon nanotubePMMA and P3HT as HTM, planar PSC achieved a PCE up to $15.3 \%$ and resistance to degradation by water was remarkably improved [49]. Ambipolar structure of $\mathrm{CH}_{3} \mathrm{NH}_{3} \mathrm{PbI}_{3}$ was verified by transistor measurement $[4,19]$. Both electron and hole transport ability pave the way for the planar device.

\section{Photoanode Morphologies for PSCs}

Photoanodes, as the support for sensitizer loading, play a vital role in the performance of PSCs. So far, several kinds of PSCs have been developed, such as nanoparticle based PSCs, onedimensional nanomaterial-based PSCs, planar devices, and flexible devices.

4.1. Nanoparticle Based PSCs. $\mathrm{TiO}_{2}$ nanoparticles (NPs) are the most common scaffolds that are used for PSCs. Due to the ambipolar charge transport nature of perovskite, as shown in Figures 3(a) and 3(b), the NPs-based PSCs can be categorized into two structural PSCs. The one similar to traditional solid-state semiconductor sensitized solar cells is 


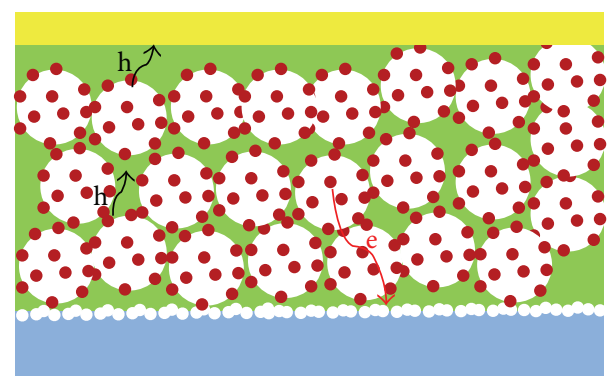

(a)
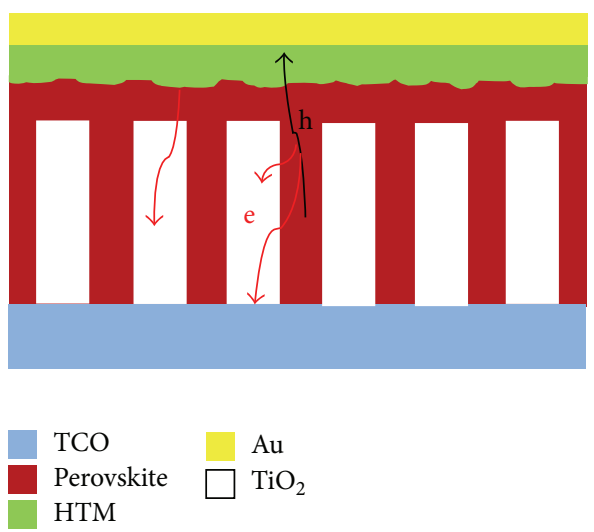

(c)

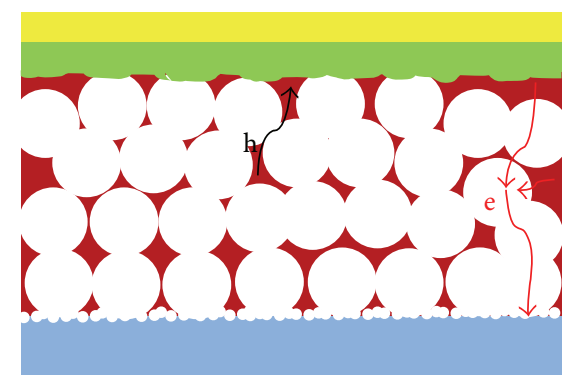

(b)

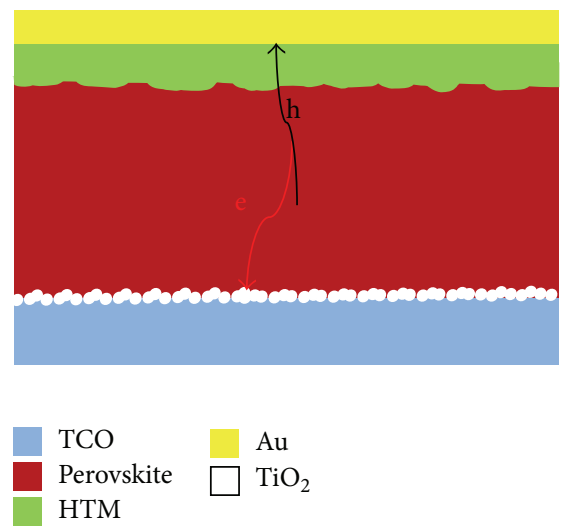

(d)

FIGURE 3: Schematic illustrations of perovskite sensitized solar cells PSCs. (a) Perovskite anchored on nanoparticles. (b) Perovskite penetrated through nanoparticles. (c) 1D nanomaterials-based PSCs. (d) Planar PSCs. Charge transport routes are schematically depicted. Red arrows are for electron. Black arrows are for holes.

shown in Figure 3(a). In this structure, the mesoporous $\mathrm{TiO}_{2}$ film usually acts as an electron extraction layer, transporting photogenerated electrons to the electron collector electrode (as the red arrow shown in Figure 3(a)), while the perovskite mainly acts as a sensitizer. The holes are primarily transported by the penetrated HTM (black arrow shown in Figure 3(a)). A representative PSC of this structure is the mesoporous $\mathrm{Al}_{2} \mathrm{O}_{3}$ based PSC, which has a PCE of $10.9 \%$, while the mesoporous $\mathrm{TiO}_{2}$ based PSC has a PCE of 7.6\% [4]. The PCE of the mesoporous $\mathrm{TiO}_{2}$ based PSC was improved to $9 \%$ [34] and to $12.8 \%$ [38] subsequently. By using commercial carbon as the counter electrode, $\mathrm{CH}_{3} \mathrm{NH}_{3} \mathrm{PbI}_{3}$ sensitized mesoporous $\mathrm{TiO}_{2}$ solar cell achieved a PCE of $8.31 \%$ with a good stability [50]. Theoretically, the liquid electrolyte based PSCs also belong to this kind of PSCs. The first reported liquid electrolyte based $\mathrm{CH}_{3} \mathrm{NH}_{3} \mathrm{PbI}_{3}$ and $\mathrm{CH}_{3} \mathrm{NH}_{3} \mathrm{PbBr}_{3}$ sensitized solar cells employed $\sim 15 \mathrm{~nm}$ sized, $8-12 \mu \mathrm{m} \mathrm{TiO}_{2}$ NP films which provided a large surface area for perovskite loading [1].

According to the literatures summarized in the Hole Transport Materials section, the unique ambipolar charge transport property of perovskites renders the photoanode no longer needed to spare much space for HTMs in the PSC architecture. Therefore, a new kind of PSC, which had the interstitial spaces between the photoanode NPs being completely filled with perovskite (Figure 3(b)), is developed. In this kind of PSCs, photogenerated electrons in the perovskite diffuse through the perovskite to the nearest $\mathrm{TiO}_{2}$
NPs and then are transported along the $\mathrm{TiO}_{2}$ skeleton to the electron collector electrode (the red arrow in Figure 3(b)). Holes are transported by the perovskite (the black arrow in Figure 3(b)). The first HTM-free PSC was fabricated using $\mathrm{TiO}_{2}$ nanosheets as a support, and $\mathrm{CH}_{3} \mathrm{NH}_{3} \mathrm{PbI}_{3}$ was deposited on $\mathrm{TiO}_{2}$ nanosheets. Such device generated a PCE of $5.5 \%$. In this architecture, $\mathrm{CH}_{3} \mathrm{NH}_{3} \mathrm{PbI}_{3}$ was believed to act as both light harvester and HTM [19]. The Au@SiO nanoparticle (NP) based PSC delivering a device efficiency of up to $11.4 \%$ was reported, in which the enhanced photocurrent was attributed to the reduced exciton binding energy due to the incorporation of metal NPs rather than the enhanced light absorption [51]. $V_{\text {oc }}$ of $\sim 1.3 \mathrm{~V}$ was obtained by a $\mathrm{CH}_{3} \mathrm{NH}_{3} \mathrm{PbBr}_{3}$ PSC on the $\mathrm{TiO}_{2} \mathrm{NP}$ scaffold [52]. In addition, mesoporous $\mathrm{TiO}_{2}$ film was used to anchor $\mathrm{CH}_{3} \mathrm{NH}_{3} \mathrm{~Pb}\left(\mathrm{I}_{1-x} \mathrm{Br}_{x}\right)_{3}$ to tune its light absorbing property and such device achieved the highest PCE of $12.3 \%$ [11]. To date, a certified PCE of $17.9 \%$ was realized by the $\mathrm{CH}_{3} \mathrm{NH}_{3} \mathrm{PbI}_{3-x} \mathrm{Br}_{x}$ $(x=0.1-0.15)$ PSC on a $\mathrm{TiO}_{2} \mathrm{NP}$ scaffold [7]. Up to now, this is the highest reported PCE for mesoporous NP-based PSC.

Unlike the dye-sensitized solar cells and other semiconductor-sensitized solar cells, different shaped $\mathrm{TiO}_{2} \mathrm{NPs}_{\text {are }}$ not the focus for PSCs. However, as is introduced above, NPsbased PSCs show a great prospect to exhibit high PCE.

4.2. NR Based PSCs. One-dimensional nanomaterials are believed to promote electron transport, elongate electron lifetime, increase diffusion length, and slow down the electron 


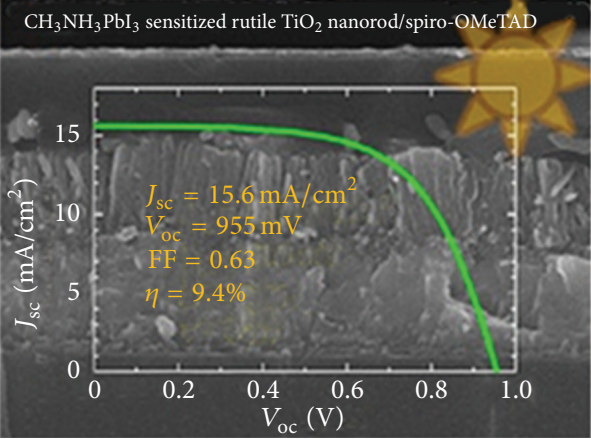

(a)

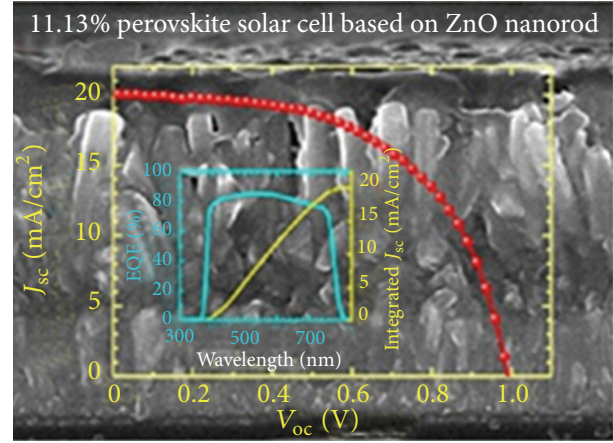

(b)

Figure 4: $1 \mathrm{D}$ nanomaterials-based PSCs. (a) $\mathrm{CH}_{3} \mathrm{NH}_{3} \mathrm{PbI}_{3}$ sensitized $\mathrm{TiO}_{2}$ NRs solar cells. Reprinted from [22]. Copyright: the American Chemical Society. (b) $\mathrm{CH}_{3} \mathrm{NH}_{3} \mathrm{PbI}_{3}$ sensitized $\mathrm{ZnO}$ NRs solar cells. Reprinted from [23]. Copyright: the American Chemical Society.

and hole recombination [53-56]. A PCE of 9.4\% was achieved on a $600 \mathrm{~nm}$ thick $\mathrm{TiO}_{2}$ nanorod array photoanode. Results showed that longer NRs deteriorated the $V_{\text {oc }}$ and the charge generation efficiency (Figure 4(a)) [22]. Qiu et al. reported a PSC with a PCE of $4.87 \%$ using $\mathrm{CH}_{3} \mathrm{NH}_{3} \mathrm{PbI}_{2} \mathrm{Br}$ as light absorber with $\mathrm{TiO}_{2}$ nanowire arrays. The PCE of this PSC was higher than that of $\mathrm{CH}_{3} \mathrm{NH}_{3} \mathrm{PbI}_{3}$ solar cell [57]. The device using $1 \mathrm{D} \mathrm{ZnO}$ incorporated with $\mathrm{CH}_{3} \mathrm{NH}_{3} \mathrm{PbI}_{3}$ also showed a PCE of $11.13 \%$ with the short-circuit current density $J_{\text {sc }}$ of $20.08 \mathrm{~mA} / \mathrm{cm}^{2}$, the open-circuit voltage $V_{\text {oc }}$ of $991 \mathrm{mV}$, and fill factor of 0.56 (Figure 4(b)) [23].

Although the literatures on 1D nanomaterial-based PSCs are not as many as those of the NP-based or planar PSCs, the superior ambipolar charge transport of perovskite does not require the large specific surface area from the scaffolds, which would compensate for the drawbacks of 1D nanomaterials. Owing to the superior charge transport of 1D nanomaterials, they might function synergistically with perovskites in PSCs application.

4.3. Planar Devices. The ambipolar charge transport property of $\mathrm{CH}_{3} \mathrm{NH}_{3} \mathrm{PbI}_{3}$ simplifies the architectures of PSCs. Because of the self-charge transport property towards electrons and holes together with the light absorbing property, the PSCs can work without the scaffold and HTMs. A simple planar heterojunction solar cell was fabricated without the metal oxide scaffold, incorporating vapour-deposited perovskite as the absorbing layer and spiro-OMeTAD as the HTM. Such PSC had a PCE up to $15.4 \%$ (Figure 2(a)) [5]. Planar $\mathrm{CH}_{3} \mathrm{NH}_{3} \mathrm{PbI}_{3}$ perovskite/fullerene planar heterojunction hybrid solar cell was developed with a PCE of 3.9\%, and its interfaces were tuned by conducting polymers, where $\mathrm{CH}_{3} \mathrm{NH}_{3} \mathrm{PbI}_{3} /$ fullerene interface was verified as the donoracceptor interface [58]. By evaporating $\mathrm{CH}_{3} \mathrm{NH}_{3} \mathrm{I}$ at $150^{\circ} \mathrm{C}$ to react with the $\mathrm{PbI}_{2}$ film, Chen et al. developed a vaporassisted solution process to fabricate a full coverage and small roughness planar heterojunction $\mathrm{CH}_{3} \mathrm{NH}_{3} \mathrm{PbI}_{3}$ device, which yielded a PCE of 12.1\% [25]. Another newly structured planar PSC, which had $\mathrm{CH}_{3} \mathrm{NH}_{3} \mathrm{PbI}_{3}$ sandwiched between two thin organic charge-transporting layers, reached a high PCE over $12 \%$ [24]. By tuning the interface states and matching the band diagram, a record PCE of $19.3 \%$ on a planar device was obtained by Zhou et al. recently [9].

The PSC PCE race joined by scientists all over the world is still ongoing. It is too early to draw any conclusion to what record PCE of PSCs can be achieved. However, the surging PCEs of planar PSCs and ease of fabrication of planar devices imply that future PSCs may adopt such simple configuration.

4.4. Flexible PSCs. PSCs on flexible substrates are advantageous for a few reasons. Such PSCs are much more portable and practical for mobile electronics, such as cell phones and laptops. They can also save more space and are not easy to break. The low processing temperature of perovskites will promote the realization of flexible PSCs.

As a part of PSCs research, lots of efforts are put into designing flexible PSCs. The PSC with substrate/PEDOT: $\mathrm{PSS} / \mathrm{CH}_{3} \mathrm{NH}_{3} \mathrm{PbI}_{3-x} \mathrm{Cl}_{x} / \mathrm{PCBM} / \mathrm{TiO}_{x} / \mathrm{Al}$ configuration was fabricated on ITO-coated plastic foil with a PCE over $6 \%$ [59]. The PCE of flexible PSC was subsequently improved to $9.2 \%$ by Yang group [60]. Carbon nanotubes were used as the hole collector and the support for $\mathrm{CH}_{3} \mathrm{NH}_{3} \mathrm{PbI}_{3}$ loading. Such HTM-free device realized PCE of $6.87 \%$. By using spiroOMeTAD as the HTM, the PCE was improved to 9.90\% [61]. By replacing the $\mathrm{TiO}_{2}$ dense electron transport layer with $\mathrm{ZnO}$ on conducting flexible substrate and adopting spiroOMeTAD as the HTM, $\mathrm{CH}_{3} \mathrm{NH}_{3} \mathrm{PbI}_{3}$ PSC fabricated at $100^{\circ} \mathrm{C}$ yielded a PCE of $15.7 \%$, which is close to the record PCE [62]. However, these achievements still seem far away for practical applications.

\section{Challenges and Perspective}

Even now, rapid progress takes place every day, faster than ever in photovoltaic field. The PCE of $19.3 \%$ realized by Yang group [9] is a huge step towards real life applications. Scientists anticipate that PCEs of 28 to $30 \%$ are feasible in the near future by fabricating perovskite and crystalline silicon cells in a tandem configuration [47].

Nevertheless, stability is still a big challenge for PSCs. $\mathrm{CH}_{3} \mathrm{NH}_{3} \mathrm{PbI}_{3}$ is very sensitive to polar solvents such as water. It readily dissolves and decomposes into $\mathrm{PbI}_{2}$ rapidly. $\mathrm{Up}$ 
to now, only a few studies on stability have been reported [6]. These reports concluded that the HTM with long alkyl chains and without deliquescent additives would reduce the water filtration and prevent sensitizer corrosion and improve the humidity stability [63]. Carbon material used as the back contact is believed to act as a water-retaining layer as well. The PCE of the device did not show a decrease after exposure to air for over 1000 hours [21]. However, there is still a long way to go to meet the rigid requirement for long-term outdoor practical applications. On the other hand, the longtime UV exposure stability is another problem for PSCs. Snaith et al. investigated the effect of longtime exposure towards UV light on the performance of PSCs. The performance of PSCs would decay due to the light-induced desorption of surfaceadsorbed oxygen on mesoporous $\mathrm{TiO}_{2}$. However, $\mathrm{TiO}_{2}$-free PSCs are protected from this instability [64].

Toxicity of heavy metal lead to people and the environment is another big concern for scaling up production of PSCs. Scientists are attempting to synthesize lead-free perovskites $[5,64]$. The PSC incorporating $\mathrm{CH}_{3} \mathrm{NH}_{3} \mathrm{SnI}_{3-x} \mathrm{Br}_{x}$, a lead-free perovskite, and spiro-OMeTAD produced a PCE of $5.73 \%$ [33]. Another alternative is $\mathrm{CH}_{3} \mathrm{NH}_{3} \mathrm{SnI}_{3}$ on a $\mathrm{TiO}_{2}$ scaffold, which achieved a PCE of $6.4 \%$ [65]. To prevent environmental pollution from lead, perovskites made from lead-free composition are likely to be the next widely researched area for PSCs. In general, before making full use of the PSC technology, all the above issues need to be addressed.

\section{Conflict of Interests}

The authors declare no competing financial interests.

\section{Acknowledgments}

Sean Hwang is much thanked for his language processing. This work was supported by the State Scholarship Fund of China Scholarship Council.

\section{References}

[1] A. Kojima, K. Teshima, Y. Shirai, and T. Miyasaka, "Organometal halide perovskites as visible-light sensitizers for photovoltaic cells," Journal of the American Chemical Society, vol. 131, no. 17, pp. 6050-6051, 2009.

[2] J.-H. Im, C.-R. Lee, J.-W. Lee, S.-W. Park, and N.-G. Park, " $6.5 \%$ efficient perovskite quantum-dot-sensitized solar cell," Nanoscale, vol. 3, no. 10, pp. 4088-4093, 2011.

[3] I. Chung, B. Lee, J. He, R. P. H. Chang, and M. G. Kanatzidis, "All-solid-state dye-sensitized solar cells with high efficiency," Nature, vol. 485, no. 7399, pp. 486-489, 2012.

[4] M. M. Lee, J. Teuscher, T. Miyasaka, T. N. Murakami, and H. J. Snaith, "Efficient hybrid solar cells based on mesosuperstructured organometal halide perovskites," Science, vol. 338, no. 6107, pp. 643-647, 2012.

[5] M. Liu, M. B. Johnston, and H. J. Snaith, "Efficient planar heterojunction perovskite solar cells by vapour deposition," Nature, vol. 501, no. 7467, pp. 395-398, 2013.

[6] J. Burschka, N. Pellet, S. J. Moon et al., "Sequential deposition as a route to high-performance perovskite-sensitized solar cells," Nature, vol. 499, no. 7458, pp. 316-319, 2013.
[7] N. J. Jeon, J. H. Noh, Y. Kim, W. S. Yang, S. Ryn, and S. I. Seok, "Solvent engineering for high-performance inorganic-organic hybrid perovskite solar cells," Nature Materials, vol. 13, pp. 897903, 2014.

[8] R. F. Service, "Perovskite solar cells keep on surging," Science, vol. 344, no. 6183, p. 458, 2014.

[9] H. Zhou, Q. Chen, G. Li et al., "Interface engineering of highly efficient perovskite solar cells," Science, vol. 345, no. 6196, pp. 542-546, 2014.

[10] http://www.nrel.gov/ncpv/images/efficiency_chart.jpg.

[11] J. H. Noh, S. H. Im, J. H. Heo, T. N. Mandal, and S. I. Seok, "Chemical management for colorful, efficient, and stable inorganic-organic hybrid nanostructured solar cells," Nano Letters, vol. 13, no. 4, pp. 1764-1769, 2013.

[12] G. E. Eperon, S. D. Stranks, C. Menelaou, M. B. Johnston, L. M. Herz, and H. J. Snaith, "Formamidinium lead trihalide: a broadly tunable perovskite for efficient planar heterojunction solar cells," Energy and Environmental Science, vol. 7, no. 3, pp. 982-988, 2014.

[13] L. K. Ono, S. Wang, Y. Kato, S. R. Raga, and Y. Qi, "Fabrication of semi-transparent perovskite films with centimeter-scale superior uniformity by the hybrid deposition method," Energy \& Environmental Science, vol. 7, pp. 3989-3993, 2014.

[14] T. Baikie, Y. Fang, J. M. Kadro et al., "Synthesis and crystal chemistry of the hybrid perovskite $\left(\mathrm{CH}_{3} \mathrm{NH}_{3}\right) \mathrm{PbI}_{3}$ for solidstate sensitised solar cell applications," Journal of Materials Chemistry A, vol. 1, no. 18, pp. 5628-5641, 2013.

[15] C. S. Ponseca Jr., T. J. Savenije, M. Abdellah et al., "Organometal halide perovskite solar cell materials rationalized: ultrafast charge generation, high and microsecond-long balanced mobilities, and slow recombination," Journal of the American Chemical Society, vol. 136, no. 14, pp. 5189-5192, 2014.

[16] D. B. Mitzi, "Templating and structural engineering in organicinorganic perovskites," Journal of the Chemical Society, Dalton Transactions, pp. 1-12, 2001.

[17] G. Xing, N. Mathews, S. Sun et al., "Long-range balanced electron-and hole-transport lengths in organic-inorganic $\mathrm{CH}_{3} \mathrm{NH}_{3} \mathrm{PbI}_{3}$," Science, vol. 342, no. 6156, pp. 344-347, 2013.

[18] S. D. Stranks, G. E. Eperon, G. Grancini et al., "Electron-hole diffusion lengths exceeding 1 micrometer in an organometal trihalide perovskite absorber," Science, vol. 342, no. 6156, pp. 341-344, 2013.

[19] L. Etgar, P. Gao, Z. Xue et al., "Mesoscopic $\mathrm{CH}_{3} \mathrm{NH}_{3} \mathrm{PbI}_{3} / \mathrm{TiO}_{2}$ heterojunction solar cells," Journal of the American Chemical Society, vol. 134, no. 42, pp. 17396-17399, 2012.

[20] J. H. Heo, S. H. Im, J. H. Noh et al., "Efficient inorganicorganic hybrid heterojunction solar cells containing perovskite compound and polymeric hole conductors," Nature Photonics, vol. 7, no. 6, pp. 486-491, 2013.

[21] A. Mei, X. Li, L. Liu et al., "A hole-conductor-free, fully printable mesoscopic perovskite solar cell with high stability," Science, vol. 345, no. 6194, pp. 295-298, 2014.

[22] H. S. Kim, J. W. Lee, N. Yantara et al., "High efficiency solidstate sensitized solar cell-based on submicrometer rutile $\mathrm{TiO}_{2}$ nanorod and $\mathrm{CH}_{3} \mathrm{NH}_{3} \mathrm{PbI}_{3}$ perovskite sensitizer," Nano Letters, vol. 13, no. 6, pp. 2412-2417, 2013.

[23] D.-Y. Son, J.-H. Im, H.-S. Kim, and N.-G. Park, "11\% efficient perovskite solar cell based on $\mathrm{ZnO}$ nanorods: an effective charge collection system," The Journal of Physical Chemistry C, vol. 118, no. 30, pp. 16567-16573, 2014. 
[24] S. Pan, Z. Yang, H. Li, L. Qiu, H. Sun, and H. Peng, "Efficient dye-sensitized photovoltaic wires based on an organic redox electrolyte," The Journal of the American Chemical Society, vol. 135, no. 29, pp. 10622-10625, 2013.

[25] Q. Chen, H. Zhou, Z. Hong et al., "Planar heterojunction perovskite solar cells via vapor-assisted solution process," Journal of the American Chemical Society, vol. 136, no. 2, pp. 622-625, 2014.

[26] M. R. Leyden, L. K. Ono, S. R. Raga, Y. Kato, S. Wang, and Y. Qi, "High performance perovskite solar cells by hybrid chemical vapor deposition," Journal of Materials Chemistry A, vol. 2, no. 44, pp. 18742-18745, 2014.

[27] M. J. Carnie, C. Charbonneau, M. L. Davies et al., "A onestep low temperature processing route for organolead halide perovskite solar cells," Chemical Communications, vol. 49, no. 72, pp. 7893-7895, 2013.

[28] G. E. Eperon, V. M. Burlakov, P. Docampo, A. Goriely, and H. J. Snaith, "Morphological control for high performance, solution-processed planar heterojunction perovskite solar cells," Advanced Functional Materials, vol. 24, no. 1, pp. 151157, 2014.

[29] Z. Cheng and J. Lin, "Layered organic-inorganic hybrid perovskites: structure, optical properties, film preparation, patterning and templating engineering," CrystEngComm, vol. 12, no. 10, pp. 2646-2662, 2010.

[30] C. C. Stoumpos, C. D. Malliakas, and M. G. Kanatzidis, "Semiconducting tin and lead iodide perovskites with organic cations: phase transitions, high mobilities, and near-infrared photoluminescent properties," Inorganic Chemistry, vol. 52, no. 15, pp. 9019-9038, 2013.

[31] B. Wang, X. Xiao, and T. Chen, "Perovskite photovoltaics: a high-efficiency newcomer to the solar cell family," Nanoscale, vol. 6, no. 21, pp. 12287-12297, 2014.

[32] Y. Ogomi, A. Morita, S. Tsukamoto et al., " $\mathrm{CH}_{3} \mathrm{NH}_{3} \mathrm{SnxPb}_{(1-x)} \mathrm{I}_{3}$ perovskite solar cells covering up to $1060 \mathrm{~nm}$," Journal of Physical Chemistry Letters, vol. 5, no. 6, pp. 1004-1011, 2014.

[33] F. Hao, C. C. Stoumpos, D. H. Cao, R. P. H. Chang, and M. G. Kanatzidis, "Lead-free solid-state organic-inorganic halide perovskite solar cells," Nature Photonics, vol. 8, no. 6, pp. 489494, 2014.

[34] H.-S. Kim, C.-R. Lee, J.-H. Im et al., "Lead iodide perovskite sensitized all-solid-state submicron thin film mesoscopic solar cell with efficiency exceeding 9\%," Scientific Reports, vol. 2, article 591, 2012.

[35] A. Abrusci, S. D. Stranks, P. Docampo, H. L. Yip, A. K. Y. Jen, and H. J. Snaith, "High-performance perovskite-polymer hybrid solar cells via electronic coupling with fullerene monolayers," Nano Letters, vol. 13, no. 7, pp. 3124-3128, 2013.

[36] D. Bi, L. Yang, G. Boschloo, A. Hagfeldt, and E. M. J. Johansson, "Effect of different hole transport materials on recombination in $\mathrm{CH}_{3} \mathrm{NH}_{3} \mathrm{PbI}_{3}$ perovskite-sensitized mesoscopic solar cells," Journal of Physical Chemistry Letters, vol. 4, no. 9, pp. 1532-1536, 2013.

[37] J. H. Noh, N. J. Jeon, Y. C. Choi, M. K. Nazeeruddin, M. Grätzel, and S. I. Seok, "Nanostructured $\mathrm{TiO}_{2} / \mathrm{CH}_{3} \mathrm{NH}_{3} \mathrm{PbI}_{3}$ heterojunction solar cells employing spiro-OMeTAD/Co-complex as hole-transporting material," Journal of Materials Chemistry A, vol. 1, no. 38, pp. 11842-11847, 2013.

[38] P. Qin, S. Paek, M. I. Dar et al., "Perovskite solar cells with $12.8 \%$ efficiency by using conjugated quinolizino acridine based hole transporting material," Journal of the American Chemical Society, vol. 136, no. 24, pp. 8516-8519, 2014.
[39] N. J. Jeon, H. G. Lee, Y. C. Kim et al., "o-Methoxy substituents in spiro-OMeTAD for efficient inorganic-organic hybrid perovskite solar cells," Journal of the American Chemical Society, vol. 136, no. 22, pp. 7837-7840, 2014.

[40] H. J. Snaith, A. Abate, J. M. Ball et al., "Anomalous hysteresis in perovskite solar cells," Journal of Physical Chemistry Letters, vol. 5, no. 9, pp. 1511-1515, 2014.

[41] J. A. Christians, R. C. M. Fung, and P. V. Kamat, "An inorganic hole conductor for Organo-lead halide perovskite solar cells. improved hole conductivity with copper iodide," Journal of the American Chemical Society, vol. 136, no. 2, pp. 758-764, 2014.

[42] P. Qin, S. Tanaka, S. Ito et al., "Inorganic hole conductorbased lead halide perovskite solar cells with $12.4 \%$ conversion efficiency," Nature Communications, vol. 5, article 3834, 2014.

[43] A. S. Subbiah, A. Halder, S. Ghosh, N. Mahuli, G. Hodes, and S. K. Sarkar, "Inorganic hole conducting layers for perovskitebased solar cells," Journal of Physical Chemistry Letters, vol. 5, no. 10, pp. 1748-1753, 2014.

[44] K. C. Wang, P. S. Shen, M. H. Li et al., "Low-temperature sputtered nickel oxide compact thin film as effective electron blocking layer for mesoscopic $\mathrm{NiO} / \mathrm{CH}_{3} \mathrm{NH}_{3} \mathrm{PbI}_{3}$ perovskite heterojunction solar cells," ACS Applied Materials \& Interfaces, vol. 6, no. 15, pp. 11851-11858, 2014.

[45] L. Hu, J. Peng, W. Wang et al., "Sequential deposition of $\mathrm{CH}_{3} \mathrm{NH}_{3} \mathrm{PbI}_{3}$ on planar $\mathrm{NiO}$ film for efficient planar perovskite solar cells," ACS Photonics, vol. 1, no. 7, pp. 547-553, 2014.

[46] J. H. Kim, P.-W. Liang, S. T. Williams et al., "High-performance and environmentally stable planar heterojunction perovskite solar cells based on a solution-processed copper-doped nickel oxide hole-transporting layer," Advanced Materials, 2014.

[47] M. Grätzel, "The light and shade of perovskite solar cells," Nature Materials, vol. 13, no. 9, pp. 838-842, 2014.

[48] J. M. Ball, M. M. Lee, A. Hey, and H. J. Snaith, "Low-temperature processed meso-superstructured to thin-film perovskite solar cells," Energy and Environmental Science, vol. 6, no. 6, pp. 17391743, 2013.

[49] S. N. Habisreutinger, T. Leijtens, G. E. Eperon, S. D. Stranks, R. J. Nicholas, and H. J. Snaith, "Carbon nanotube/polymer composites as a highly stable hole collection layer in perovskite solar cells," Nano Letters, vol. 14, no. 10, pp. 5561-5568, 2014.

[50] F. Zhang, X. Yang, H. Wang, M. Cheng, J. Zhao, and L. Sun, "Structure engineering of hole-conductor free perovskite-based solar cells with low-temperature-processed commercial carbon paste as cathode," ACS Applied Materials \& Interfaces, vol. 6, no. 18, pp. 16140-16146, 2014.

[51] W. Zhang, M. Saliba, S. D. Stranks et al., "Enhancement of perovskite-based solar cells employing core-shell metal nanoparticles," Nano Letters, vol. 13, no. 9, pp. 4505-4510, 2013.

[52] E. Edri, S. Kirmayer, D. Cahen, and G. Hodes, "High opencircuit voltage solar cells based on organic-inorganic lead bromide perovskite," Journal of Physical Chemistry Letters, vol. 4, no. 6, pp. 897-902, 2013.

[53] G. Peng, X. Xu, F. Mei et al., "Substrate placement angledependent growth of dandelion-like $\mathrm{TiO}_{2}$ nanorods for solidstate semiconductor-sensitized solar cells," RSC Advances, vol. 4, no. 95, pp. 53335-53343, 2014.

[54] B. Liu and E. S. Aydil, "Growth of oriented single-crystalline rutile $\mathrm{TiO}_{2}$ nanorods on transparent conducting substrates for dye-sensitized solar cells," Journal of the American Chemical Society, vol. 131, no. 11, pp. 3985-3990, 2009. 
[55] W.-T. Sun, Y. Yu, H.-Y. Pan, X.-F. Gao, Q. Chen, and L.M. Peng, "CdS quantum dots sensitized $\mathrm{TiO}_{2}$ nanotube-array photoelectrodes," Journal of the American Chemical Society, vol. 130, no. 4, pp. 1124-1125, 2008.

[56] G. Peng, J. Wu, Y. Zhao, X. Xu, G. Xu, and A. Star, "Ultra-small $\mathrm{TiO}_{2}$ nanowire forests on transparent conducting oxide for solid-state semiconductor-sensitized solar cells," RSC Advances, vol. 4, pp. 46987-46991, 2014.

[57] J. Qiu, Y. Qiu, K. Yan et al., "All-solid-state hybrid solar cells based on a new organometal halide perovskite sensitizer and one-dimensional $\mathrm{TiO}_{2}$ nanowire arrays," Nanoscale, vol. 5, no. 8, pp. 3245-3248, 2013.

[58] J.-Y. Jeng, Y.-F. Chiang, M.-H. Lee et al., " $\mathrm{CH}_{3} \mathrm{NH}_{3} \mathrm{PbI}_{3}$ perovskite/fullerene planar-heterojunction hybrid solar cells," Advanced Materials, vol. 25, no. 27, pp. 3727-3732, 2013.

[59] P. Docampo, J. M. Ball, M. Darwich, G. E. Eperon, and H. J. Snaith, "Efficient organometal trihalide perovskite planarheterojunction solar cells on flexible polymer substrates," Nature Communications, vol. 4, article 2761, 2013.

[60] Y. Yang, J. You, Z. Hong et al., "Low-temperature solutionprocessed perovskite solar cells with high efficiency and flexibility," ACS Nano, vol. 8, no. 2, pp. 1674-1680, 2014.

[61] Z. Li, S. A. Kulkarni, P. P. Boix et al., "Laminated carbon nanotube networks for metal electrode-free efficient perovskite solar cells," ACS Nano, vol. 8, no. 7, pp. 6797-6804, 2014.

[62] D. Liu and T. L. Kelly, "Perovskite solar cells with a planar heterojunction structure prepared using room-temperature solution processing techniques," Nature Photonics, vol. 8, no. 2, pp. 133-138, 2014.

[63] J. Liu, Y. Wu, C. Qin et al., "A dopant-free hole-transporting material for efficient and stable perovskite solar cells," Energy \& Environmental Science, vol. 7, no. 9, pp. 2963-2967, 2014.

[64] T. Leijtens, G. E. Eperon, S. Pathak, A. Abate, M. M. Lee, and H. J. Snaith, "Overcoming ultraviolet light instability of sensitized $\mathrm{TiO}_{2}$ with meso-superstructured organometal trihalide perovskite solar cells," Nature Communications, vol. 4, article 2885, 2013.

[65] N. K. Noel, S. D. Stranks, A. Abate et al., "Lead-free organicinorganic tin halide perovskites for photovoltaic applications," Energy \& Environmental Science, vol. 7, no. 9, pp. 3061-3068, 2014. 

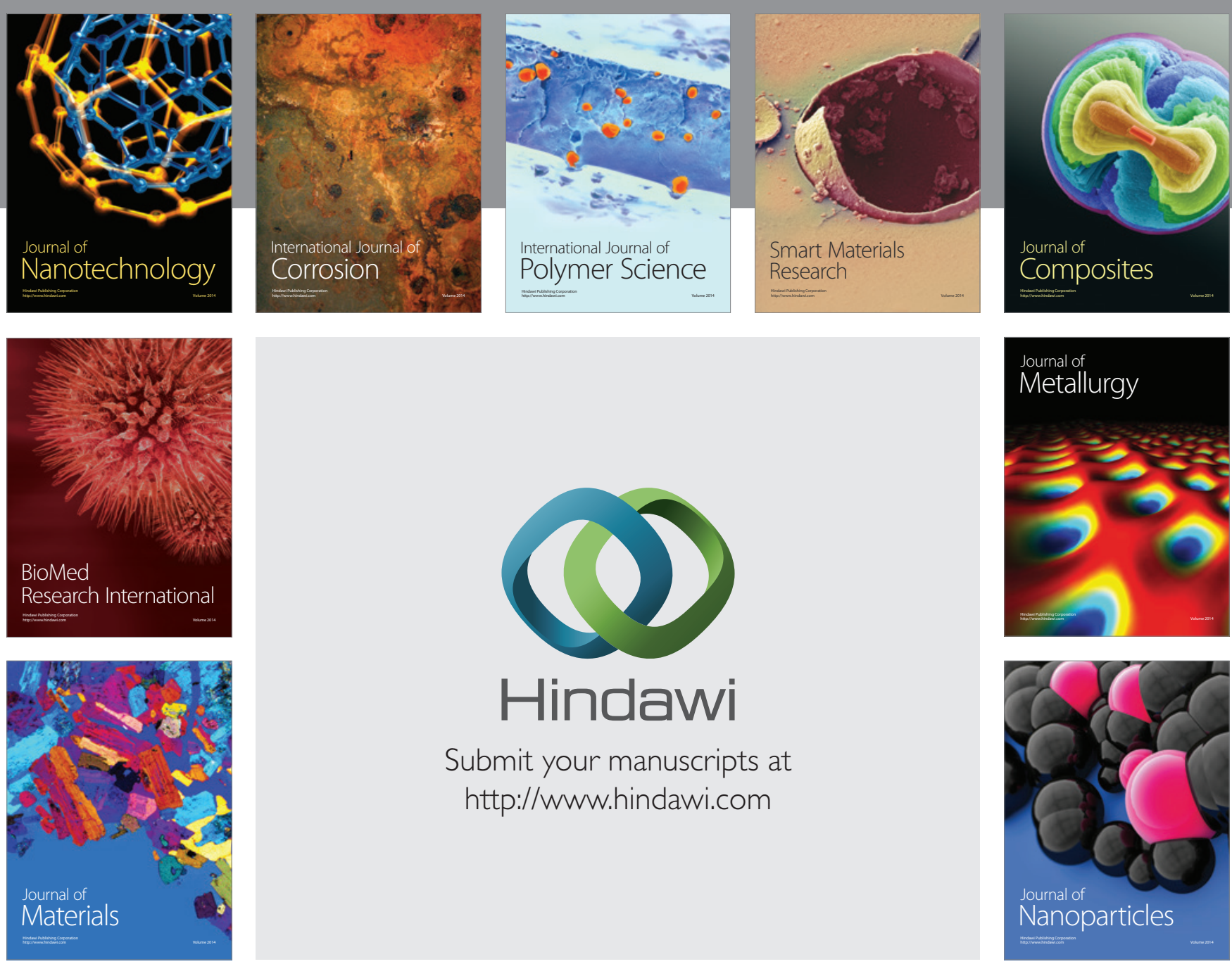

Submit your manuscripts at http://www.hindawi.com
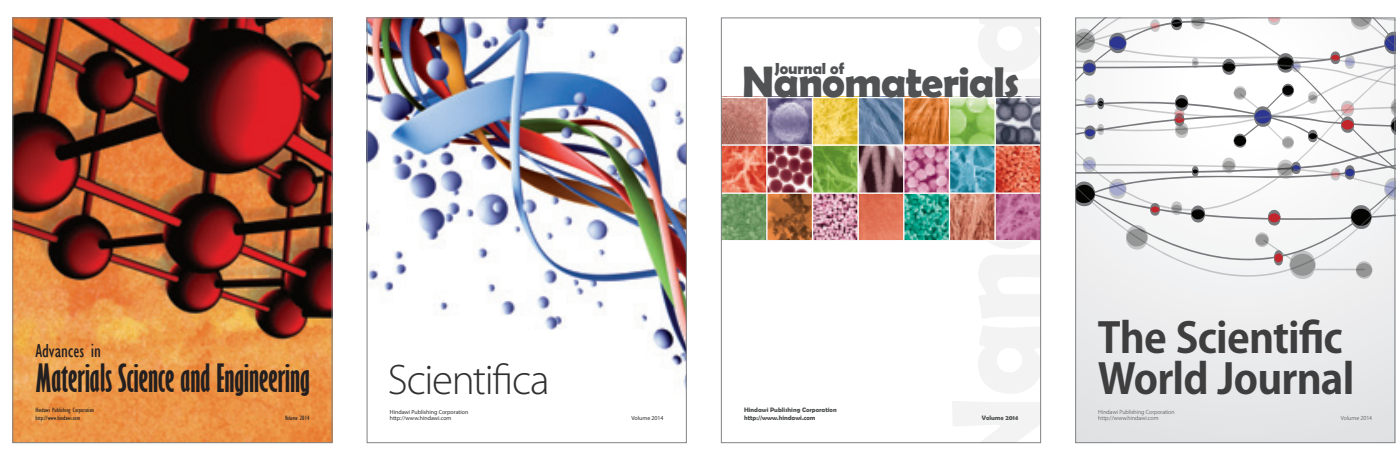

\section{The Scientific World Journal}
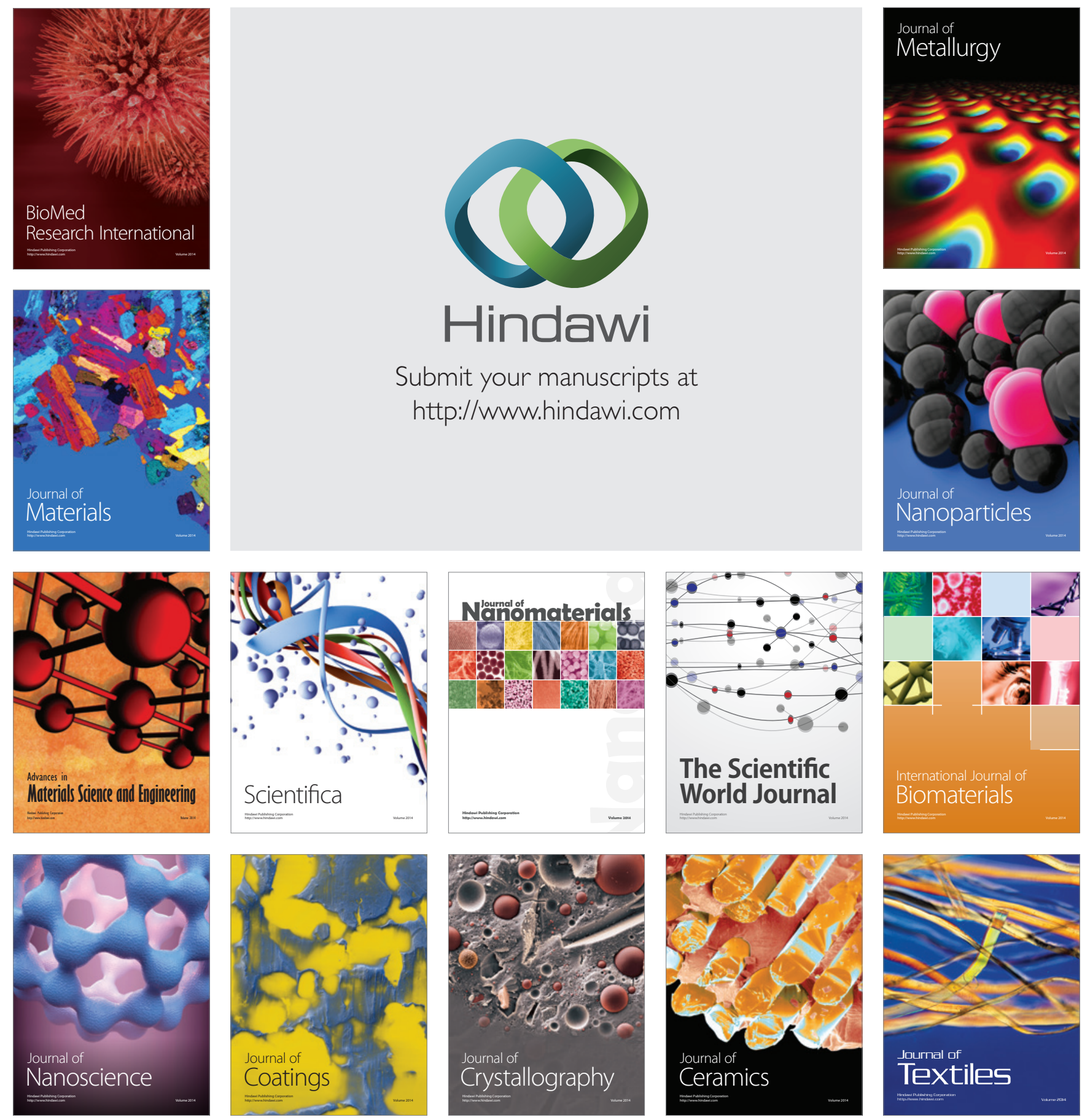